\title{
A REVIEW OF RESEARCH ON
}

\section{DELETERIOUS SUBSTANCES IN}

\author{
CONCRETE AGGREGATES
}

$$
\begin{gathered}
\text { DEC.. } 1957 \\
\text { NO. } 37
\end{gathered}
$$



TO:

B. B。 Woode, Director

Joint Highway Research Project

Decermber 18,1957

FROM: HoI。 Hichael, Asalatant Director

P1le: $5-9-5$

Attached 18 a report entitled, "A Review of Research on Deleterious Substancos in Concrate Aggregates," by Rn L。 Schuster, Research Assistant on our stafr.

Thie report sumarizes the research conducted in the Project Laboratories and in other locations on deleterious substances in concrote aggregatos. It was made at the request of the Board at 1ts meeting on Septerabor 18, 1957. This action was taken as a result of the Highisy Departmently new speciflcatione concerming the amount of chert.

The report is prescnted as information.

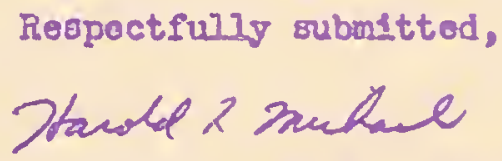

Harold In Michael, Assistant Director Joint Highway Rasearch Project

HL: hgb

Attachment
ce: A. Ko Branhan
R. D。 14108
J. R. Coopor
R。 E。 K1L13
Wo Io Dolch
B. Ho Potty
W. H. Gootz
H. B. Scott
J. Ts Hallett
C. E. Vogelgesang
F. F。 Havey
J. Lo Waling
G. A. Hawlins
Jo E。 H17zon
G. A. Leonards
J. Fo Kclaughlin
E. J. Yoder 


\section{TECHNICAL PAPER}

\section{A REVIEW OF RESEARCH ON}

DELTMERTOUS SUBSTANCES IN CONCRTTE AGGRTGATES

\section{by}

Robert I, Schuster,

Research Asststant

\section{Jolnt HIghway Research Project \\ Profeet No, $\mathrm{C}=26-42 \mathrm{E}$ \\ File No. $5=9=5$}

Purdue University

Laîayette, Indi ans

Decenber 18, $195 ?$ 
EARLT RESEARCH ON DELETERIOUS SUBSTAYCES

IN CONCRETG AGGREGATES

The presence of certain rocks, inineralz, and other alibinnces may greatly impair the quality of concrote mado ith aggregates contalning only saall percentages of these meterials. The term "deleterious substaneag" or "deleserious constituentg" has become a comon one for describing this clasa of materials.

Deleterious substances aro those winch advorsoly affect the concrote in which thoy aro used. Theso substances nay be categorized on the basis of the nature of theis haraful. effects (1) . The nost harmful. class of deloterious matarials consisis of those which tend to expand dismptively due to induced siratns resulting from westher Ing of the deleterious matorials. The most cormon examples of this cless are porous cho:ats ${ }^{2}$, well-indurgted clays, and 1imostones contalno ing expansive clays. Such raterdals, when frozon in a saturated cont1o t1on or in some casos, when merely expoged to water, incraase in volume with derelopaent of sufficient prossure to cause deop-seated disintegration of this coneseten

In another close of deloterious cubstancs the aggregate

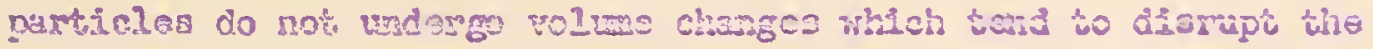

$\underline{1}$

Mrmber in parantheses refer to the 11st of cited reforences whtch 2 oppoare st the ond of this reportio

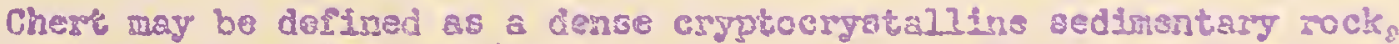

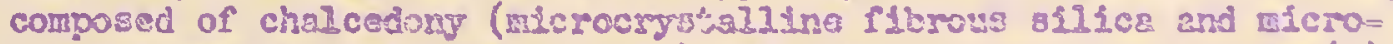
fibrous amorphous silica or opal) and cryptocrystalline quests (2). It has a tough splintery to concholial fresture. It is corronity wite.

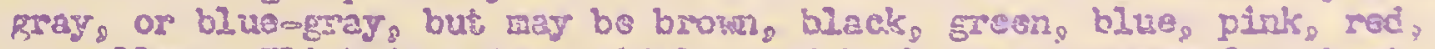

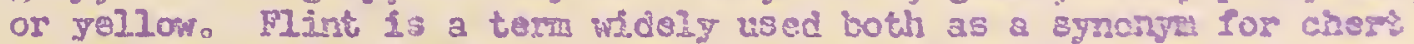
and as a varioty of chert. Tare (3) states that fint is ldentica whth chert, and rocomends that the term bo droppsd iron geofogic usage. Although the tern flint antedates the term chert, presentoday lisage favors the latter as the propsr dosignstion of the matarlals to which both terms have beei applied (2). 
Digitized by the Internet Archive in 2011 with funding from

LYRASIS members and Sloan Foundation; Indiana Department of Transportation 
surrounding mortar. Instad they break into numerous sualler pieces due to the inherent structural weaknssoes of the particles themselves. Framples of such deloterious substances are clay lump; ochers, poorly Indurated shalez, and sofi Eandistones. Dopending on tho ouantity of thoso materials used in tho concrete, daterioretion may be gensial or more often, may be orscience primarly by surfaes pltting or scallig Other matsrie.s wich are comonis classifled as deleterious are organic inpurities and lightweight pieces, inciuding coas, lignite, and wood. Organic inpurities generally retard the soting of cament and roduce concrsto strongih, particularly at early ages, Finsiy dividod coal, lignito, or rood in eufficient quantity will also re= tard hardening, howerer, those matorials generally occur as small quantities of largor pieces which have no signiflcant effect on the strength of the concrete but may detract from its appearance by producing aurface pi亡s.

It has long boen recognized that certain typos of aggregates have harmful efiects on the concrets in which they are used. It was not unt.t the $3920^{\circ} \mathrm{E}$, however, that much research was begur in thio couniry which attenpted to cuantify the effects of those aaterials which vere sugpected of boing doletorjous; and thus, to doterrine the quantities of these natsials that could be included in concrets aggregates. During the construction soason of 2.923 s Ragel (4) notfced a peculiar surface effect on the cancrete pavements constructed in cerialn localities in Hissouri. Investigation showed that portifons of the surfaco averaging $I$ to $1-i / 2$ Lnches in dianetor were cracking 
loose from the paventont and could be pried out or wore later d1splaced by traffic, leaving a holo with 3loping oldes from $1 / 2$ inch to 1 inch in dopth. On romoval of a large numbor of thoso "popouts," It was discovered that the pluce of pavement loosenod always contained a largo fragnent of char aggregate at the bottore while the remainder of the plece of aggregato was laft forming the bottom of the hole in the parement. It wis evident that tho force acting to raiso the "popo out" occurred in 211 cases through the aggregate, The action never occurred in connection with pieces of Iimestone, of wintch the greater part of the coarse aggregate in the pavement consisted, but aiways just abovo or through a pices of chort.

Reagel then conducted an investigation which showsd that these "popouts" wero due to frost action on the pieces of chert. He subjocted aggragatos wich ware high in chert content to sinple freezo Ing and thaning tests in the leboratory. Thse teats waro conducted on both tho loose aggrogate and on corcrete beams in which the aggroo gate containing chert we incorporated thoy consisted of five cyoles of altemate freering and thawng. The results of these tasts showod that the looso chort was seriously affected by the tests and often disintograted completoly. The tost beams showed a definito Ioss of atrength; and, in cases where larga percentages of chert were Included in the agsregate, they often disintegrated to tho point whoro they could not support thsir own welght.

Rosgel noted that the five cycles of Irsezing and thawing which he used in these tests wart considerably fower than could ordinarlif be expected in an average winter season in Misscur1. Sinco fivo 
cycles of frealng and tharlug often producsd sovore djsintegration of concrete made from the chert aggregate, he concluded that chert should be linited to the amalost percontage posaible in azgregates to be used In the production of concrete.

In 1924, Withoy (5) outilinsd the varlous tests which had been devaloped by that tiue fox testing the durability of concrate assregatea. Four typos of teats wore then in use: (e) tho freezing and thawing test, (b) the sodiun suiphate soundnees teat, (c) the sodium chloride teot, and (d) the alkali test. Each of these methods wes Intonded to give an accolorated tost of the potentsal durability of the aggregate. The teste fore conducted on the loose aggregato, not on concrete specinens in wich aggrogate was incomporated. Withey auggested that these tests should be thoroughly invastgated since they whould not differ matorially in thell erfects from those produced oy netural agencie3. Ho noted, for Imstance, that the sodsu suiphato tost Ghould not be nsed to approximate the erfects of natural frecaing and thawine?

In 1928, Scholer (6) Btatec that, "The use of unsound aggreo gate produces unsound concrste, the resistance of ths mortar to disintegation belng only silghtly effective in protecting the eggregate." In ordor to doteraino which aggregates regulted in non durable concreto, ho deFoloped a wothod which tosted tho resistanco to preozing and thating of concrete cylinders rada from the eggregatos in quastion,

Using Irsozing and thawing tasts of concrete, Scholer (7) continuad his research on varlous aggregates which were suspected of containing 
substances which were harmful when used in concrete. In the Kanses aggregates which he tostod, ho fourd that the moet common and rost destmuctivo deleterious aubstances wore absorptive chert in gravel and flinty concretions in I1mestone.

Walker and Proudley (8) studied the effects of shale on concrete durablilty and reviewed other investigations of shale, ocher; sandstone, and light=rolght particles. They concluded that soft. frtablo, and non=durable particles are detrimental when used in concrete, and they noted that although investigations of these substances in concrete aggregates had ylelded valuable information, these investigations had not provided a conclusive basis for fixing specification IImits. lost specification liajts at that time were based strictly on englneering judgment formed from a consideration of the service records of the aggregatee and from a consideration of the econcmics of the problere in a fiven localitys

Runner (9), in 1937, was one of the first to geriously apply petrography to the atudy of deloterious substancos in aggregates. He found that it was possible to determine the probable durability of aggregates by means of studies using the petrographlc microscope. He made thin ssctions of aggregate parifeles and studied then under the microgcopen He was able to identify the harmful types on the basio of norosity, texture, and rineral composition.

In 1938 , Litehisor (10) published the results of investigations of the offects of Ohio aggregates on conerete durability. Using the freezing and thawing tost doveloped by Scholer (6) and the sodiu 8uiface soundness test, he found that shale, ifronite ochers henatites 
Lron pyrites, and some varioties of chert had detririental effocts on the concrete in which they were useds He noted that not all var1et1es of chert were dolotarious, but did not suggest a means fir" telling tho difference between deleterious and nonodeletoriois cherts.

In 1939, Cantrol11 and Campbell. (11) published the results of a concrete pavenont condition survery thery had conducted in Rentucky. Analysis of their data showed thet serfous fallures of concrete parements throughout tho wostern part of Kentucky were due to the use of chert gravele obtained from the Tonnessee and Cumberland Rivors in the western pars of the state. Pavenents in wh!ch these chert gravels were used ofien began to disintegrate witiln one year after construction。

The results of this surrsy led Cantrill and Carpboll to a labora tory study of the wostorn Kentuchy cherts. They found these cherts to be extrenely porous, highly absorpitive, and possessed of a low spectfic gravity. The chert gravels passed all the standard laboratory tests for abrasion and soundiness which wars used at that tine, These were: (a) The Ios Angeles Abrasion qest, (b) the Deval Abrasion test, and (c) the Sodium Sirphate Soundness Fost. Also, strength tests on chemtogravel concreto field specinens showod valuee comparablo to those for specimens made frow Onio River grovel or crushed line. Btone with good servico rocortan Howerer, when the chers aggrogate was incorporated in concrate bosms ard subjected to 40 cycles of freszing and thawing in water, a definfice reduction in flexural strength was noted. It was thus concluded that freezing and thawing was the cause of the disintegration of these lightwef gint Kentuck chers when used 
In concreto pavements.

In $134 \mathrm{O}_{2}$ Wuorpel and Roxford (12) publishod the results of thoir invegtigation of the pooplbility of sepacoting durable and noa-durable variotios of chert in concreto coarse aggregato by som moanc more prociso than visual exanination and more prectical than mf.roscopic analyol: In thoir papex, they included a symposium of related comments by other investigators. Included In this symposium aro the following 3 igntflcant cowonts from tho Corpo of Ingsnsers: Rock Island Anveatigation (13) 8

1. "Heating and cooling of chers has absolutely no efrect. This tost was inst.tatod to allay some suppositions that choret caused "popouts" in surmertine due to heat of the sun followed by a cooling rain or vica veras."

2. "Mhose results (freosing and thaving of paraffinocoated chart in mostar speejuens) Indicate that popouts occur only Proa freeding of water absorbed by the chert. Ihis hypothesis is further voripied by a conparison of the absorption and apeciric gravity of each type of chert with its roaction to froozing and thawing It seeno a gereral wale that a chert stome with an absorption greater than 3 porcent or an apparent apociflc efravity losg than $2.50 \mathrm{can}$ be clessified as hamaful naterial. "

Wuspel and Rexford collected esmples of cherty gravel from ten areas in tho southom, coniral, and esstem portions of the United States. These mors separated Into four bulk-spoclffcograytty sroups by heavy liquid flotation using bromofora (specific gravity 2.86) and monombromobenzero (spscific gravity 1046). The groupe used had specific gravities of 2.50 plus, 2.40 to $2.50,2.30$ to 2.40 , and 2.30 minus. Material in each group was analyzed picroscoplcally and tested phyisically for absorptivo capacity rosistance to frost action and resistanco to a magnesium sulphate soundness test. The results of these tests showed a dofinito increase in absorption and decrease in 
soundness with lower bulk speciflc gravity of the samploa, These trende wore present for all groups lower in bulk specific gravliy whan 2.50, but wore especially noticeable in the pebbles hoving a bull: apecific gravicy of less than 20.00

These reaulte compared favorably with the results of a perfornance survey af the axposed concreto structures in the areas fron which the gravelo had been obtained, A group of 100 roughly confcal "popouta," each having a piece of dj.8mpied chert at the apex, was collocted ivor loprasentativo siructures, In every case, the piece of chert had an absrption groater than 4 percant and a bulk gpecific gravits loss than 2040

On the basis of thio irsostigation, Wuerpel and Rexford concluded that tho f'lotation mothid of specific gravity separation Lo the most practical method of separating durable from non-durablo cherts. They recomiended that the flotation test be used as a field test for the separation of a majority of the non-durable chert in concrote aggregate. In addition, thoy devalopod a flotation field kit to bo ueed for this purpose.

In thetr discusston of the prseeding study by KurpeI and Rexe

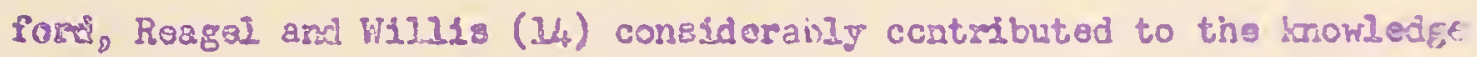
of tho durability characteriatica of chirt. Their research was conductod on a Hissourl chert-rich grevel coarge aggregate Hit' is poor service record in conerate pavensits, Thds aggregate, as produced for concrete pavemert, had an avarage buik spacific gra.Ity of 2.5 and, in the strean-wet condition, 3.8 percent abso:sed nolsture. 
By veans of a technique similar to that used by hurpel and Rexford (12), ths saturated aggregate was soparatod into three fractions of different buli specific gravities, namely, less than $2.4,2,4$ to 2.5. and over 2.5, Theso threo coarse uggeegate gravity fractions ware then Incorporatid in 3-1/2mby $4-1 / 2$ byel6-inch beamo which, after a 28 -day curing perfod, wore subjectod to consecut1\%o cycles of fresting in air and thawing in water. Apter $1,3,5,7,9$, and 20 cycles, the dymamic moduluo of elasticity and the specimen iength were determined for each of the beams。

Tise results of these teste showed that, for the particular aggragat employod, realstanco to the freozing and-thawing cyele used was much greator for tho concrete containing tho aggregate fraction of greatsst bulk spacific gravity thai for that containing aggregate fraction of lorer gravity. The results also indicated that remorel of the low-mavity aggregate fracticns (I0ss than 2.50) and use of only the higinst fractions (over 2.50) produced conerete that was more resistan; than that in which tho unseparated etreamom gravel was นยอั.

0.10 of the princlpal polnte brought out by Reagel's and Fil1118: tosts sal that concreto mado from oren tho highest gravity fraction (all paricles oror 2,5 and an average bulk epsciflc gravity of 2.58) of this shartorich aggregate having a poor sersice rocord showed consideribly loss resiatance to freczing and thawing than that of a non-cheri aggregate with a good service record: 
EARLY RESEARCH ON DELETRRIOUS SUBSTANCES

IUT INLIA.NA AGGHEGATES

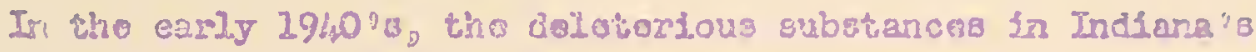
aggregates begar to bo oxposed to corprohensivo study. In 1942 E Swoer anr. Woods (15) publiohed tho regulto of their thosough Lnvestigrtion of chert in Indiana's aggregater. They identifled the chert in samples of 3ggregete and studied it by means of chemi= cal and riferoscopic analyges, minoralogical examination, absorpticn teat $3_{8}$ ard freezing and thawng curability tecto. Thoy rocognized the fact that all cheris aro not unsound, and aticapied to find a means of differemtiating betweer. curable and non-durable varlettes. Thag consi dered unsourd aggregates to bo those which are unable to

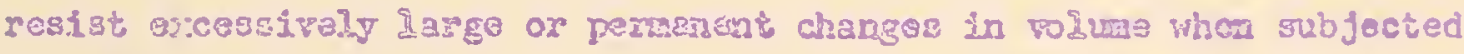
to dostrictive agencios, particulardy froozing and thaming heating and coofing or vetting and dsying

Thie Pirst Giep in this gtudy was the collection of samples from quarsios and grevel deposits. Approminately fourthousand pounds of chept ware secured fron the olx State Highway Districts in Indians, and from sources in IIIinois, Kenituck, Kichigan, Missouri, Oho, and Tennussse. The Indi2sı Istge rock samples rers obtainad fros 29 gुuarries and highwy cuts, and the gravel samples from 31 gravel depostts in all parts of Indiana.

I. was decided to teet the porformance and properties of the guarry staples first, because the propertles of the individual piocss 
In erch sample wore reasonably uniform. Ladge chists were obtainsd fron quariy faces and 1dont1fiod geologically. record was mado of the macroscopic character of each sarple, In:Luding colors luster

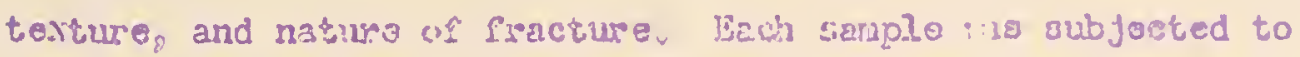
perfermance and Identification tortr.

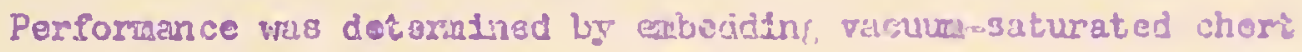
pebblos in mortar cubes and subjecting the cr:es to alternato cjclgo of freezing and thawing. The blocke wore fn.sen in water for 21 hours ot $10^{\circ} \mathrm{Fo}$ and thon wore immersed in reior at $75^{\circ}=80^{\circ} \mathrm{F}$, for throo hours. This procodure was soposted uilil 40 cyclos had be: reached. At intervale tho cubes wore examined for signo of cracking. On tho basis of thess testa, the cherte we: divlded into tro groups: (8) those which disrupted ths euhes 51 to $: 00$ percent of the tivie in 2808 than 40 cycles; and ( 0 ( those which iscrupted the cubes 0 to 50 percont of the time in 40 cycles. So:e of the quarry chert types which proved nowadurable in this tagt wero invostigated furthar to detoralns the effect of altesnations of temperatusen

Identification tegts of tho quarsy cherts consigted of bult: specific Eravity, absorption, degras or saturation, dge penstratifon, unconfined freesing and thawing, chenfou, analyses, anci ulcrogcopic exarination of thin soctions. The nost usoful resulte were those from the sposifle grevity and abcorption tests, The cherts in group A (thoss which diumpted the cubes 51 to 230 percent of the time in lese than 40 cycies) had an avorage bull speciflc gravityp eaturated

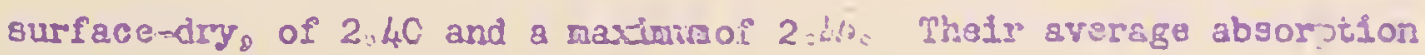


wae 5.36 pereant and ths ralnimu aboorption for exoup A charts was 3.91. porgent

Simples in gxoup 3 (those cherts which d1ompted the cubes 0 to 50 sercent of the tine in 40 cycles) avoraged 2,58 in tulk specific grastty, satarated Burfacedry, with a minimum of 2,48 Abaorption of cherts in this group averaged 388 porcent with a. mestoura of 3.02 percertis

The ogne geroral performane test pior:edure erplcyed on tho quarry chorts was used to dotermino the durablilty of the gravel chertes, Plecos $3 / 4$ inch to $l$ inch in 3120 wore plcked at randon from samples of gravel chert from Irdiane and other states. These 7rsre evesuated sor oro hour, gaturated, and Immersed for 24 hours. Ih war w then enbedded ln two-1rsch mortar cubas, The vortar cubos

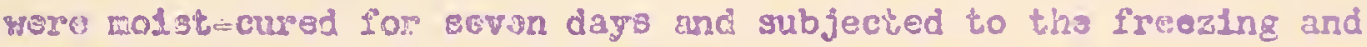
thawing test. Tho grarel cheri specirong that falled in th13 test wero zemoved from tine broken mortar and eubjected to the folloring Idontification tosta: colars \&exture, bulk speciflc gravity by the Molation procodure, dye panctration, apparent specific grevity? absorption, dogreo of saturailosg and mieroscopic araiyis. The nonefaling spochome were ieeroved from the freezing and thaning teas: at the and of 40 or 160 cycles, brokers frost the cubes, and then analyzed, using the sams ldertification tosts as wero uBed with the fall ures,

A wodification of the flotation nethod developed og Vherpel and Rexiord (12) for decterniring tho bulk spsciflc gravity of gravol particies wes used in separating tho chert samples into different 
fxactions on tho basis of thoir specific gravity. Carbon totrachioride, opecific gravlty $1.05 \varepsilon_{0}$ and acotyleno tetrabrouldo, spociflc gravity 2.97, were mixed together to give liquide whth epecil1c gravitios of $2.60,2.55,2.50,204.5,2040,2.35$, and 2.30 . A Bravol specimen that had boen broken out of tho mortar cubos was irmersed in water. After It had soaked for 24 hours, it was surface dirled and placed in the heaviost Ilquid (2, 60$)$ ). If it sank in this liquid, it was removed, and the specific gravity was recorded as 2060 plus. If it plated on the 2.60 liguid, it was removed and placed in the 2.55 11quid. This was sepented fos each piece until it sank is one of the liquids. If a pioes floated in the I1gintoes Ifguld $(2,30)$ sts specific gravity was recorded as 2,30 minus.

In this way it was possible to obtain a correlation between the bulk apocific grevitys saturatod eurfacedry, of a piece of chert, and Its parformance in the froosing and thaining testo The results of these studies showed that the average bulk spociflc gravity. eaturated gurface=dry of unsound chert was lower than that of ourablo chert. They indicated that an uppor Ilmit of 2,30 detected entirely ungatisfactory matsrial; 2,45 detected alnost all tho very harnful types, and included littlo ciurable materialo A limit of 2.50 ircluded almoet all the nohndurais meterial and also a somewht larger amount of rolatively durablo particles than did the 2.45 limit.

Fren though Stest and Woods found in these tssts that no sharp line could be drawn between entirely cound and ontirely un = sound chert on the basis of specific gravity, they were abie to set 


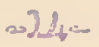

up the following tablo as a relative mosure of the probablo perforance

of Indiana chorts in concrete based on the bult., saturated eurfacendry? spocific gravity:

$\begin{array}{lll}\text { Below } 2.30 & \text { - Unsatlafactory } \\ 2.30-2.45 & - & \text { Poor } \\ 2.45=2.55 & - & \text { Falr } \\ 2.55=2.60 & - & \text { Good } \\ \text { Abovo } 2.60 & - & \text { Excellent }\end{array}$

It should be noted that in this chart proposed by Sroot and Woods, the break botveen "goca" and "bad" cherts was found to occur at a spocific gravity of 2.45. This savo speciflc gravity is in uso today by the Indiana Highway Dopartnent as the level of soparation botween durable and ron-durable cherts.

The absorpticn of a piece of aggregate is ordinarily directly related to the specifle gavity of the piece Bince, in most ceses, the absorption of a material is degendent upon its poresity (16). Porosity 16, an turn, directly ralated to the bulk speciflc gravity of tine material. Therefore, the relative aboorption of an aggregats partele may be used as an Indication of the durability of the particle in the sare way ae bulk specifle gravity.

A simple means for measuring tho reletive absorptivity of aggregates нав usød by Sweot and Woods. Thsy solected pobbles sbout ien/2, inches in diemater, partially surnersed thes in a one-percent solution of watersoluble eosine dye for a given period of time, and then measured the depth of penetration of the dye. They found that the greater the penetration of the dye, tho lower the durabllity of the chert. On the basis of theso tests, they proposed the following 
tablo of onowhour dye penoliration deptho to bo usgd for predicting the relative durability of Indiana gravel cherts:

\begin{tabular}{|c|c|c|c|}
\hline 0.25110 & or more & $=$ & Unset1 i factory \\
\hline 0,2011 & $-0.24 " 1$ & - & Poor \\
\hline $0,10^{\prime \prime}$ & $=0.19^{11}$ & m & Pai下 \\
\hline $0.04^{n}=$ & . $0.09 "$ & $=$ & Good \\
\hline 0 & $-O_{2} \alpha_{4} "$ & - & EyrceJJ.ent \\
\hline
\end{tabular}

RECFNT RESEARCH ON DELETERIOUS

SUBSTANCES IN INDIANA AGGREGATES

In 1947, Soon (17) carried out a series of tebts on coarss aggregate irom efght sourcas of supply commonly used in concrete pave. ments in indians in which he attempted to determine the relationship of field and laboratory performance of the aggregeto samples. H3 dfvided the samples into bults spacific gravity ranges by means of the heayy- lfquid flotation process, and pieces from each range woro enbedded in tro=inch mortar cubss and were subjeated to freezing and thawing action. The cubes wore placed in pans contsining about an Inch of water and frozen for 22 hours at zero to ten defrees Fahrenheit, They were then inmerged in water at 75 to 50 degrees Fahrenheit for thres hourso Thlo procenturs was repoated until faflure of the cubes or until a given number of cycles was attained. In the failure of a cube, the usual process was tho appoarance of cracks which progrosejrely becano wroge with each cycle of freesing and thating until the iractursd cube courd bo pulled spart by hand using a moderate arount of force.

On the basis of the results of these tests, Soon conclided that 
Indliane eggregates aro increasing?y durable in the following order: (a) soft particles, (b) cherts, (c) Iinestones below 2.50 in buik specific gravity, (d) sandstones, (o) shales, (f) Ilmestones above 2.50 spociflc gravity。

Venters and Lorle (18) furthered the etudy of the doletorious constituentic of Indiana eggrogate by soparating large samples of gravals into frackions having different specific gravity ranges, and testjng these gravels for absorption, degres of gaturation, and dursbility as irdieated by the freening and thawne durability test. The freering and thawirg tost was conducted on 3 -by-amby-16 Incis conerete bean in which difforent ageregate fractions were used. The test consiated of freezing in air at minus $15^{\circ} \mathrm{F}$ 。 to mines $20^{\circ} \mathrm{F}$, and thawing in running tap wates at $55^{\circ} \mathrm{F}$ to $60^{\circ} \mathrm{F}$. One cycle per day was obteined, whit 16 hours freezing and 8 hours thaw Lng. Porriodic cotorminations of tho dynamic modris of alasticity were made to meabure the dotexioration of euch 3pecinen.

The reaults of those tosts showed tinat the eggregates with low 8psciflc gravities were characterized by high absorptions, high degrees of saturaticn, and poor durability in conerete subjected to freesing and thewing: The deleterious substances in the lormsteciflc gravity iractiars ccosisted meinly of chorte and sandstones witi lesser anount of Agnocus, calcaraous sedinentsry, and metamorchlc rocks, Tho poor fragenthew durablity of concrets made with tho low-3pecific gravity aggrogatas kas of grogt jmportance bacaubo Venters ard luen $1 \mathrm{~s}$ found that those grevels in this study which had low specifle gavitios 
280 had poor fleld records.

As a result $\mathrm{cf}$ their Investigation, Venterg and Lowlo suggested that incseased durablitty of concrete prodnced in actual construction could be obtained by tho use of fleld heavy-kediam3oparation procesgos. They stated that seraration at 2,40 epecific rravity would improve the durability of pcor aggregates considerabiy and goparation at 2.50 world result in aggregate with good durabilsty

Wialker and Hoitenghin (2.9) experinented furth: with combinations of Indians aggragates. They used heovyoliguid soparatin to obkain from gavels vartous fractions with differont mindenus spoc: fic gravitios, They then used these fractions, alons or in coxbintion with goodoquality crushed stone, in ccrczete hich wea tested fo: durability in rreozing and thavingo

The gxarels which wers studied all had high chert contents, The: contained from 10 to 70 parecent chert, Although the epocific ETavity soparation rewoved other low-gpectfic grevity materials also, nost of tho raterlal rexowal was cherto

Walker and Molaughlin found that remcral of the lowospeelf:c gravity fractions from the grarol aggragares resulted in a cancrate of

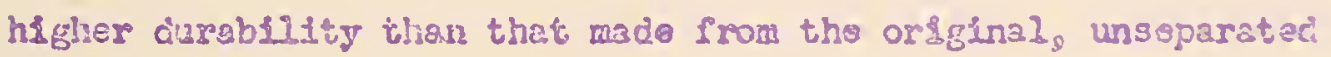
aggregate. Also, concreto made with crusher stonemgravel combinations; where the graval usod had poor sorvice rocords, was mads more ciurable with the heavy-liquid seperation. They also found that the durabiliti of conerete made with gravel aggregates alone compared farorably with the fleld performance of the aggragates, thus Incilcating the 


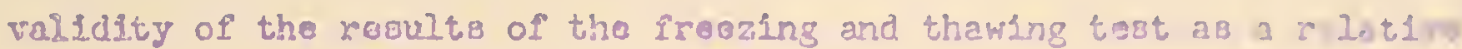
Indication of the durablilty of concrete

\section{INDIANA HIGHHTYY DEP ARTNIS!T \\ SPECIFICATIONS GOVFRING DELEIIITIOU LUBSTAICE3}

Ou the besis of ths resezrch provioubly described otine resarch

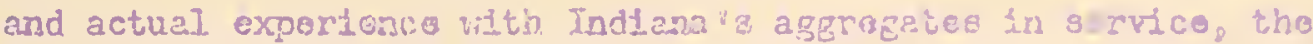
Indiana Hghwaf" Departuent"s 1957 standard stecificatfors for daloterlous materials in cosres asgrogatss (20) have been tabulated as shorn in Table In The cheri requiremat in these speciflcations roflocis the otatement that roi all, varfetles of chert ere deistericus Thjs reguirement, which 13 basad on the spoclfie Esavity of tha cherh, is a direct rosilt of the reseasch corrolating specific eravity of $c$ or, whth 1ts durability when includod in consete aggregato, 
TABLE I

REQUIREMTLNS FOR DELETERIOUS MATFRTALS IN INDIANA S COARSE AGGR FGTES*

\section{l.sgregate Clas}

Deloterious biatorlas

(porcent by weight), not more than:

A $\quad \underline{C}$

Clay lumper

0.2

02

Ochers

1,0

2.0

Shoils

0.7

I. 0

I

Sort or nondurable particles

$4.0 \quad 4.0 \quad 0$

Surie of ail. tho abovo, not rore than

5,0

$7,0 \quad 10,0^{2}$

Choxt; (1038 thas 2.45 bulk specific gravity)

I

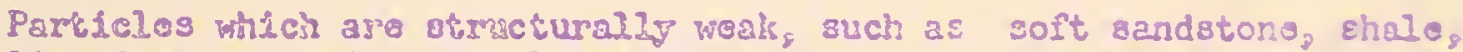
limonito concrettons, cols, woathered schist, un comsented grevel. Ths sum of all tha above soft and non wurable particles ohall not exceed 400 parcent.

2

Doos not include clay lumpso

3 Bulk spsefflc grevity shall bo determined in the saturated surpacedry condition.

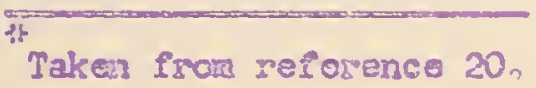




\section{REFERENCES CITED}

1. Hioem, D. $L_{4}$ "Soundnese and DeloterLous Substances," ASTH Specisl Technical Publication, No, 169, Signiflcanco of Tests and Propert108 of Concrote and Concreto Aggregates, yp. 346-352, 1956.

2. Pott1john, Fo Jo, "Sodimentary Rocks," Harpor, New York, 1957.

3. Tarr, W. A., "Ferminology of tho Chenlcal Silicoous Sodirents," Report of the Cormittes on Sodirantation. $1937-1938$ Nat1onal Research Counc11, ppo 8-27, 1938 ;

4. Reagel, F. Vo, "Chort Uaf1t for Coarso Aggregate in Concroto," Ingineoring NowB-Reoords Vol.938 pp. 332.0334, 1.924

5. Wtheg, M. O, "Soundness Tosts for Coarse Aggregates," Proceedings, Iilghway Rosoarch Board, Vol。 4o ppo 109w117, 1924

6. Seholor, C. H., "Some Accelorated Freozing and Thawing Tests on Concrote " Proceodings, American Socicty for Testing Matorials, Vol, 28, Part 2y ppo 472 486,1928 .

7. Scholer, G。 Hig "Durabllity of Concrote," Proceeding B, Highway Rosaarch Board Vol。10, pp. 132-163, 1930。

8. Waller, So, and Proudloy, $C_{0}$ E. "Shale in Concrete iggregates," Proeesilnga, Highway Research Board, Voln 12, Part 1, ppo 273-203. 2932.

9. Runner, $D_{n} G_{n}$, "The Value of Potrography in Deternining the Quality of Rociss, Public Rosds. Vol. 18, pp.69-74, 77, 1937.

10. Lftehioor, $R_{0} R_{0}$ "Effect of Deleterious Materials in Caneroto," Rock Products, Vol, 41, Ho, 9, upo 39-40, Soptomber i938.

13. Cantrill, $C_{0}$ and Campooll, $I_{1,}$ "Solestion of Aggregates for Concrote Paveront Bessd on Service Records, "Proceadings, Aterican Soclety for Tosting Materialo, Vol. 39, ppo 937-945, Discussion; p. 946. 949, 1939。

12. Wuerpal, $C_{0}$ Eo and Rerford, $E_{0}$ Pog "The Soundiness of Chort as Heasured by Bulk Speclif Gravity and Absorption," Proceodings. American Society for Testing Jaterials, Vol, 40s ppo 1021-10438 Discussion, ppo 2044=1054, 1940 .

13. "A Treatise on Chert," $U, S$, Enginoer Office, Rocik Island, IIInols: Kay, 1937。 
14. Rorgel, $F$; $\nabla_{0}$ and W11J.19, To $F_{8}$ "D18suesion on tho Soundness of Cham "Procosdings, American Society for Tosting Haterials," Vol, 40, ppo 10!7.01051, 1940。

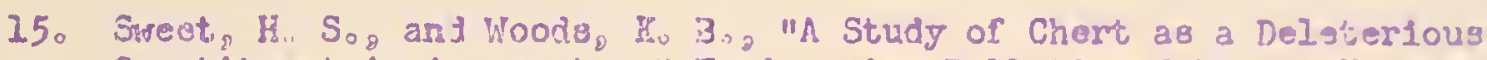
Constituent in Aggrogater," Inglneoring Bulletin of Purduo Univeroity, Vol. 26, No, 5, 3aptaubor, 1942 .

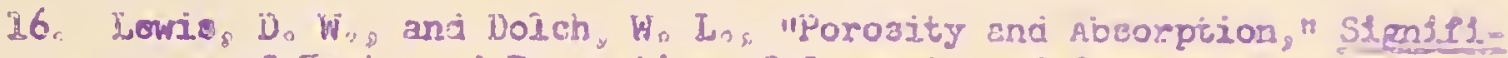

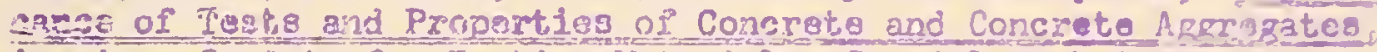
Anorican Socioty for Testing Hatorial, Spacial Technical Publ1cation $170,269,50303-313,2956$.

17. Soon $A_{0} C_{3}$ "Concrote Ageregaic Study," A thesie suboitted in parilal fulfillment of tha roquirenonts for tho degree of liater of Science in C1vil Engineoring, Purciue University. 1947.

18. Vonters, Z. and Lowis, D. Wo, "Dolotorious Conot1tuents of Indina Gravelg" Heghwa Rosearch Board Bulletin, No, $9 \%$ p. I to $10_{2}$ 2954 (Finginosing Roprint of the Joint Highwa Rosearch Project No. 206)

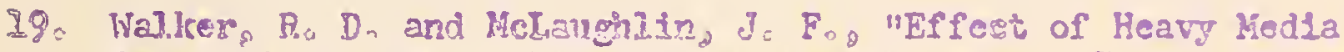
Separation on Durabliliy of Cancreco MEde with Indiana Gravels," Hiphar Rogearch Board Bulletin No, 143, poo 14-26, 1956 (Engineering Ropoint of the Joint Hs.ghvay Rescarch Projget $\mathrm{No}, 226)$ 。

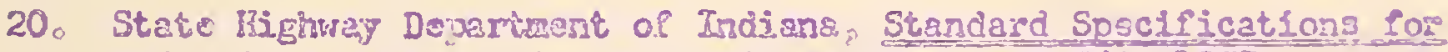

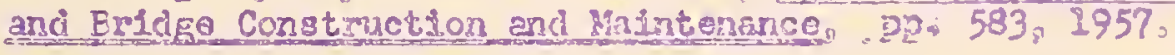

\section{A.DTITONAI REFTRINCES}

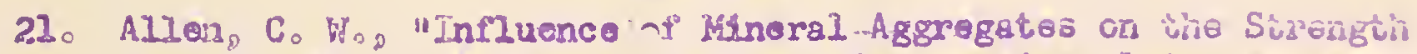
and Durability of Concrote, Symposiuga on Mincral AgErogates: Arerlcan Sorlets for Tosting Hatcrials, Spocial Pechnical Puiotication Mo. 83, ppo 152.159, 9.948。

22. Axon, Eu Oo, Will1s, $T_{0} F_{0}$ and Reagol, $F_{0} V_{3}$, "Iffect of Air= Entrapping Portland Canant on the Rosiotance to Frsezing and Tharing of Concrete Contalsing Inferior Coarse Aggregate,"

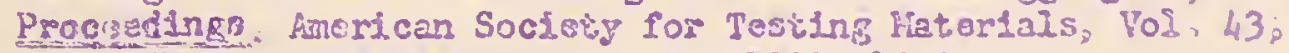
ppo 982 994. Discussion, ppo $995-1000$ s 2943

23. Friege, Ho Fo, "The Stability of Chert:" Rock Products, Fo1. 32, Ho, 9. ppo, 50-53. April 27. 1829.

24. "Tang. F, Con "Delotorlous Substances," Rerort on Stenfficasco of Tests of Concret. And Concret. Asgregates, Ansrican Societ. For Pesting Materials, Spaciai Technicel Publication lio. 22, Firet Fdition, ppo 96-102, 1935; Second Edition, ppo 138-if4s 1943 . 
25. Lang, Fn Co, "Deletorlous Substancos in Concrete Acerogatce „" Bulletin, National Sand and Gravol Associatton, May, 1931.

26. Legg: FoEog Jro, "Freozo-Thrw Durability of M1chigan Conerato Coarge Aggregatej," Highway Resoerch Basrd, Bulletin 143, op. 1-13. 1950

27. Lewhe, D。 Wo, WEfect of Coarse Agerogato on Corcroto Pavensnt Perfurmance In Indians, Ijphnay Research Abstract8, ppo $15-23$. Iบx, 195 แ.

28. Lew15, Do $W_{0}$ and Wocue, $K_{;}, B_{3}$, "Pessarch a Related to the

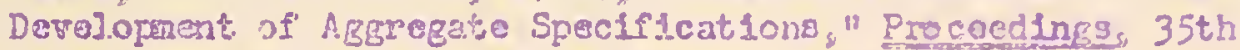
Annue I Puxduo Road School, Excension Series Hoo 69, Vol, 33. Ho. 5. 2po 155-173, Septerabor, 1949.

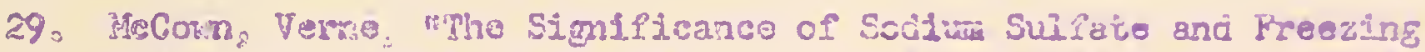

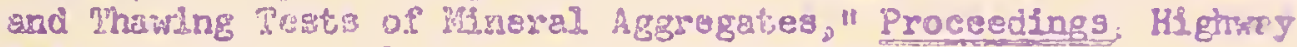

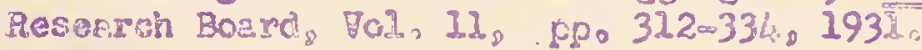

30. Mfolenz, R。Cog "Potrographic Fxamination, "Slemificence of Teste and Propertos of Concrere and Concroto tesrogates" Anorfean Socloty for Tosting Matartals, Spoctai Fechaical Fublication Ho. 169 , pp. $253-273,2956$.

3.. Miolenz, $\mathrm{R}$. C "Petrofrephlc Examination of Concroto Aggragate" Procredings, Arerican Socioty for Testing Materials, Yolo 5i, ppo 1288-121?. 195ik.

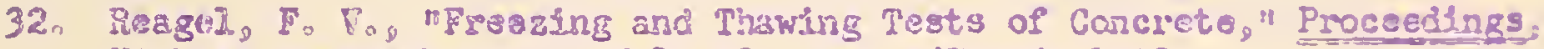
Highvey Roseareh Board, Volo 20, ppo 587.595, 1940 ,

33. "Ehoàcios, Roger, and Ifishona, R, C., "Poirographíc and úlnoraloglc

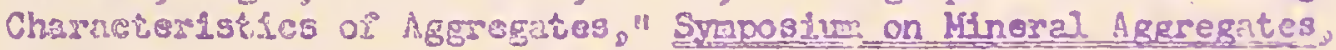

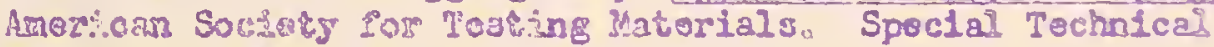

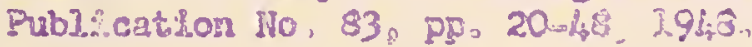

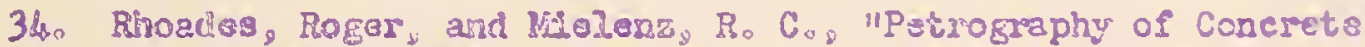
Aggrogato.". Proceodings, Anirican Corexste Insitute, Volo 12. ppo $\quad 581-600,2946$.

35. Sweot, ho $S_{0}$ " "Chem 38 a Dalofsrdous Constitutent in Irailaza AgEregates" "Procosdings, HI Hars Research Eoard, Vol, 20 p Ppo $593=620,2940$.

36. Sriear, H, S, "Cuserere Durablitty ss Affected by Coarse AggreBates," Thes IE (Subinitued to Purduo iniversity in pertial fulPlinent of the riquiraments for tine degrce of Doctor of Philosophy): 3948 . 


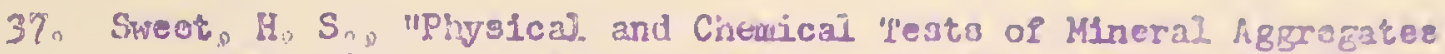

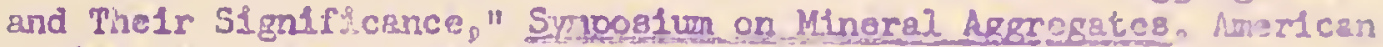
soskety for Tescing Matorials, Special Technical Fublication No. 83, ppo 49-73, 1948 .

38. Sweot, H. So. "Rerearch on Concroto Durability as Affocted ug Coare Aggregats" Proceoditigs, American Socioty for iesting Materiale Vo1. 48, ppo 98ti-1016, 1948.

39. Swect, $H_{0} S_{2}$, and Woods, Ko B., "Evaluation of Aggrogate Perforwanco In Pavement Concretes" Journal, Americen Consrato Institute. Fed, 19, ppo $1033=1040$, Juns, 1948 ,

40. Swerson, E。 Gos and Chaly, $\nabla_{0}$, "Elasie for Classifylng Delectorious Charectordstics of Concroto Aggregate Nateriais" "Procedings. Amer1sen Concrate Invitiut, Vol. 52, 1956; Jorumal, American Conerete Institus, Yol 27, No, 98 ppo 987-2002, $\mathrm{day}$, 1956,

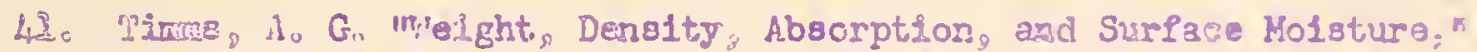
Signf fioance of Tests and Properties of Concruto and Concrete Apgiesates, imericen Societj for Testing lateriels. Specias Technical Publication No. 169 , pro 297-302, 2955

4. Walker, S, "Freszing and Thawing Tests of Concrete Hade with Difreront Aggrogates": Proceedings, Arerfean Concrate Inst ltute, 7ol. 40, ppo 573, 1944:

43. Walker, So, "Projuct1on of Sand and Gravel, Journal. Anorican Concreto Insticure, ppo 165-178, October, 1954; Proceodings. Vol, 51, FR, 65, 1954

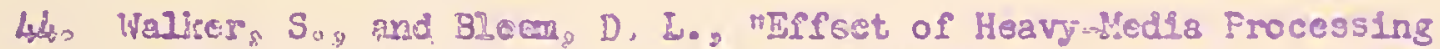
on Cuality of Gravel," Circuirx No 55. Naticmal Sand and Garel Aseociz.tion, 1953.

45. Waller, So, and Blour, Do L "The Problen of Delotertous Particles in Aggregetes, "Circular No. 35. National Sand anc

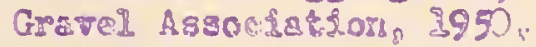

46. Wite, $L$, V. and Peyton $R$. I., Condition of Concrete Parenants In Rensas as hffocted Coaros Aggrogato," Procesdings, Highway Research Board, Volo 25, ppo 129-146, 1945 .

47. Witheys Fo Oos "Progross Report, Consittae cn Durability of Conereto." Procesaings Highw Research Bcard, Vol. 24, p?. $174-2.02,1944$ 。

4.8. Woods In B., "Aggregates ind Their Influence an the Durability of Concreto:" Crushed Stone Journal. Vol. 25 , No, $l_{p}$ pro 21 . Harch, 1950. 


$$
\infty 21, \cdots
$$

49. Woods. KO Bo, "Correlation of Coares Aggrogato with Perfomanco of Portind Cement Conerote" CL- Lu?ar No, 49, liational Sand and Craval Aszocinilon, April, 1952 .

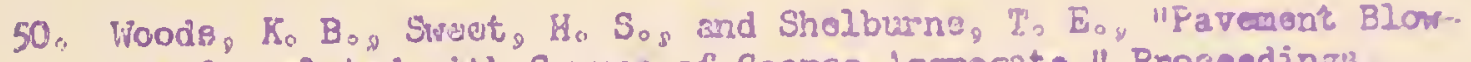
ups Correlated with Scurce of Coarae Aggrogate," Proceeding" Hifhway Resosrch Board, Volo 25, ppo 147-268, 1943.

51. Wherpel, $C_{0} \bar{E}_{0}$ "Dcterting Unoound Chert in Ageregatos," Engineoring Nerro-Record, Vol。 124.0 ppo 652-65L, 1940 o 
APPENDIX

\section{A Rerlow of the Ifterg.ture on the Effeet of Ass Entrainmen on the Durabluty of Concrete Made from Aggregates Containing Chert}

It has been shom that entrained air occurs as minute, discomected air bubbles uniformly diatributed tinrough the concrete. Thess air bubbles, when incorporeted in paving concrote, produce a materlal wh1ch is rom markabiy resistant to the scaling which may bo associated with the removel of snow and ice by the use of chemicals.

In the widdle $1940^{\circ}$ st was theorlzed that alr entroinment could also be used to improve the durability of those concrete which are ousceptible to freesing and thawing failure because they contain unsound coarse aggregates. Considerable research was begun et that tine in an attempt to verify this hypotheris.

In 1943, Axon, Willis, and fleagel (1) fabricated afrentrained congrete kest beams from four differant Missourl cosrse aggregates: two creshed limestones, and two etierserch fivar grsvels. The two Ifrestone aggregates had good servieo records; one of the chers-rich grevels had a falr service reeort ninile the other had procuced only concretes with poor durability. Eech of thoso canse aggregeten vas usad, In a saturated condifion, in three separste bstches. one of these batches was wade with plain portind cement and contained sbout 1 percent alr The other two bstehes contained a blend of plsin esmens and cement gxound wth 0.3 parcent rinsol resin to gire enirgined ats contents of 4 and 7 persent for tine rospoctive batches iffer euring, 
the beams from thoso batchas were subjocted to the freezing and thawng test, and their floxural strengths vero measured.

Posults for both 11 mestone concrates contalning ontrainad alr showd a definite improvemant in durability as mossured by the freeziag and thaving testo Howover, for concrete wade with the chert-ich aggregate with a falr service racord, tho use of entrained abr resulted in only a sight lncrease in durabilityo. In the case of the chert-rich aggregate with a poor durability record, the use of entrained air resulted in no appraciable improvenent in durabil1ty. Axon, W1llis, and Rergel concluded that thore 1 on ony a slight chance that alrentraiment will approciebly reduce the sato of dialntegration vesuling from ireezing and thaving of courerte containting unsound aggregates.

In his discussion of the previousit clted paper, husepel (2) briefly presented the results of sinilas studies which he had conducted Por the st. Lawronee Waterway Project. In these studios a very inforlor Eravel was compered with aggregate of good qualityo Plain portland cemonte and vinsolorestn-kreated cements ware used wish these aggregates, and It was found that the nurability of the alpentreined coscrots spscimens containing tha good agresetes wa very auch better than tbat of the plain conerste specimens containing similar aggregates, but there was a relatirely insignisicant improtenent in the dursbility of the conerete with the inferior quality fravel.

In 1944, Iindray (3) investigated the relative durability of alpontrained poriland cemene conerete and reguiar poriland cemeri concroto made witb chertarich aggregates. The aggregates used were stream-ogeturated gravelso Ifttio or no improvensnt in durability ${ }_{0}$ sulted from the use of the alroentrained port land eament. 
In the wame year, Reagol (4) published the remults of further experinonts of this type. Tho testy concucted by Reagel wero almilar to those used by Axon, Willis, and Reagel (1) in 1943. Ay in these earlien tests, he 1nvestigatod the effects of air entralment on conerete made frosn two saturated chert-rich gravels and two erushed Iimestone aggregatos as measured by reaistance to laboratory freezing and thiwing, His results shosed that entrainod air improved the durebility of concrete containing elther medioere or good limestone aggrogates, but cused no approclable improvement in the durabilsty. of conerete containing chort-ireh ageregates.

In 1947, Bugg (5) Investigatod the effects of air entrainment on conireto containing Indiana aggragatesn He used the same tcchniques as previous investigatoro exeept that some batches were made using aggregatev which vere vacuur seturated while for othor batches the aggragates were merely innersad in sap water at room temperature for 24. hours. Bugg worked with four different aggregates: two crishad limestones and two chertorich gravelso One of the limestone aggregates hed a good fleld performance record while the other had only a fas record. One of the cherborich gravels contained only 9 pereent chert and had a fair rield performanco recosdo. The other chert-rish gravel contsined 43 percent chert and had a very poor steld performance record. Concrate beams made from those aggregates and rom elthar regular or alpantrelned possland cement wore subjected to the freezing and tharing tost. From the rosults of this study Bugg concluded thas under the condifion of the rreezing and thawing test and with the Exaterlats used, af rentrained concrete showed sifght to condderably grester 
durability in every condition investigated than did regular cement conerete. However, it should be noted that the Breatert improrenent was shown by the imwersed aggregates。 Later studes by Sweot (6) have shown that 24 hour Immersion doos not approximste tho high degree of saturation that mainy rivor gravels have at the tim of their production for aggregate. Sweet also found that freezing and thrising of laboratory fabricated concrete beams produeed resulta that were in accord with the fleld porfomance of the materials ured when the aggregate was incorporated in the conerete in a molsture condition corresponding to this field saturation. At lower degrees of saturation, aggregates with poor service records were highly realstant to the laboratory freezing and thawing testso Sweot's rowearch indicates, therefore, that the rosults of the Eeats which Bugg andueted or the conerete rade from the Immorsed aggre= gates may not be truly indicative of the sthution existing in the pavements.

For the saturated aggregates Bugg ${ }^{0}$ result wers actusly simlas to those obtained in saruler studies by other investigatosso He found thet als ontrainent improved tho durability of concrete wade from the limestone aggregates and from the ehertsich aggregato with a fair performance recordo Ths improvement shown by the saturated aggregate contriving 43 percent ahert, howevar, was not appreciable except whero percentages of antrained afr were wsed which vere large enough to serLously affect the strength of the conerete.

In 1948, Blackburn (7) published the results of a study of the Preaze and thaw cussability of seven Indisns aggregetes used in conerete with rasying ats contents. The puspose of this stuat was to datermine the effect of asr entrainment on the durability of enerete eade with 
Certain aggregates which were chosen on the basts of the1s aborptro and performance characteristics as boing fairly representative of those avallable in Indlana. Two aggregateg used by Bugg (5) were usod as a mean of comrelating the two studieso Tho aggregater were insorporated In concrete teat bams which were subjected to freozing and thawing as in the preeding tests. The air content: of tho varlous concrete batcheg used for making these beams varled from 0.1 to 10.9 parcent, Blackburn's results closely paralloled those of Buggo He found that aif ontrasment improred tho reststance to Iroezing and thewing of Bonerete made from all aggregates which hid only been immersed fo: 24 hours and thus were not fully saturetedo Also, those aggregates which had been recuum seturated but had falr to good fleld porformance records also showed consicerable improfentento Only she saculu saturated aggregate wh a poos wervice recon falled to renpond marisedy to the use of onfrained alro This aggregate was a rirer gravel conbaining 9 persen

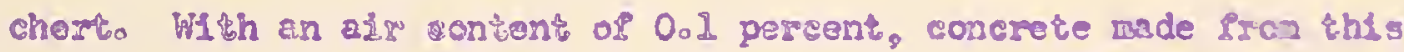
gravel tas highly saturated and morks seilure resulted. Als contont ss high as 10,9 porgent falled to rake this aggregato durable in coneserc when If tras verumi sntursted。

The consonsus of the results of the several studis revewad in this papor secas to bo that although ontralned atr does inprove ths durabilsty of conerete made from aggregates with fal so good fleld performance reconds, 1s has Iftile, if any, offect on the durablilty of berpolch aggregates with foo floId potsormance rasords. 


\section{REFERENCES CITED}

1. Axon, Eo Oo, Wlll1s, To Fo, and Roegel, Fo Vo, neffect of Alr entrapping Portland Cement on the Resistance to Freezlng and Thawing of Concrete Containing Inforlor Coarso Aggregate," Procecdings, Arerican Sockety for Testing katorials, Vol, 43. ppo 981-9914, 1943。

2. Wherpel, Co Es, Discussion on "EPfect of Alrentrapplng Porlard Cement on the Resistance to Freczing and Thewing of Concreto Contelining Inferior Conrse Aggregate," Proseedingy, American Society for Testing Materielis, Volo 43, fo 995, 1943。

3. Lindsay, Go Lo, Mamfacture and Use of ALrentraining Portland Cement," Journal, Amarican Conerete Institute, Volo 15, No. 6, ppo. 529-536, June 1944。

40 Reagel. Fo Vo, "Alroentraining Agents Not a Curo $=11, x$ Journal, Americen Concreto Inetitute, Vol. 15, Noo 6, ppo .563-567, June 294/3

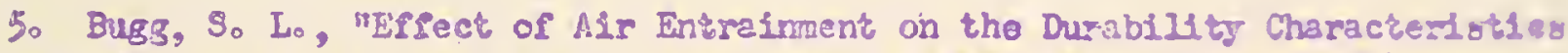
of Concrete Ageregates," Proccedings, Higtney Research Board, Volo 27. ppo $156-270,194 \%$

6. Sweat, Ho So, Discussion on ". Breeze and Thaw Durability of $A$ is $=$ intrained Congrete Using Indiana Azsregates" Propeedings, Highray Research Borrd, Volo 28, ppo 187-194, 1948。

7. Blakburn, Jo Bo, "Freeze and Thaw Drrability of AL=Entreined Con cref, Using Indiana Aggregates, "Proceciings, Highas Rosearch Bosrd, Volo 28, p. 271-287. 

